\title{
Seasonal Variation of Food composition and Feeding Activity of Small Adult Barramundi (Lates calcarifer, Bloch) in the South west Coastal Water near Khulna, Bangladesh
}

\author{
*Syeda Mushahida-Al-Noor, Sheikh Kamruzzaman and Md. Delwer Hossain \\ Department of Fisheries, Faculty of Agriculture, University of Rajshahi, Rajshahi 6205, Bangladesh. \\ *Email: munianoor@gmail.com
}

\begin{abstract}
The food habits of juvenile Lates calcarifer in the Shibsha river were investigated by examining the gastro-intestine contents of 720 specimens collected from June, 2010 to July, 2011. The major component of the diet was teleosts were dominant (32.40\%) found in the stomach of Lates calcarifer. The next major food group were macro-crustacean (22.65\%), followed by zooplankton (17.16\%), algae (10.40\%) and insects $(9.89 \%)$. Monthly fluctuations were also witnessed in the percentage occurrence of stomachs with different degrees of fullness. It is evident that higher percentage of fullness of the stomach was recorded in pre-monsoon due to pre-spawning fattening process. Higher percentage of emptiness of the stomach was recorded in monsoon, due to starvation during breeding seasons. It is also observed that the percentage of stomach fullness was higher in summer than the percentage in winter in juvenile $L$. calcarifer.
\end{abstract}

Key words: Coral, White sea perch, food and feeding habits, Cock-up perch, Bangladesh.

\section{Introduction}

Barramundi (Lates calcarifer,Bloch) is a brakishwater fish and commonly known as "Cock-up sea perch". It is locally called as "Vetki" in Bangladesh. L. calcarifer is a commercial important euryhaline fish of Indian sub-continent and it grows to comparatively large size with delicate, flovoured flesh and commands high price in the markets (Das, 2000). Lates calcarifer are valuable both as recreational and commercial fish, with a high, fairly stable price (Luna, 2008). It has become a vulnerable in marine species due to over exploitation (Cheung et. al.,2005). It is available in seas and estuaries of India, Ceylon and Bangladesh to throughout most of northern part of Eastern Indian Ocean, western central pacific area and south ward to northern coasts of Australia, also westward to Karachi (Fishcher et al., 1974). Some other reports stated the evidence of $L$. calcarifer in Bangladesh (Rahman, 1989), India (Kapoor et al., 2002), Pakistan (Bianchi, 1985), Myanmar (Hla Win, 1987), Sri-lanka (Pethiyagoda, 1991), Thailand (Yadav, 1999) and East Africa (Kungvankij et al., 1986) have been found.

L. calcarifer is a diadromous species (Kungvankij et al., 1986), inhabiting rivers before returning to the estuaries to spawn. Small adult Barramundi inhabit the upper reaches of rivers (Allen et al., 2002). Some 
Syeda Mushahida-Al-Noor, Sheikh Kamruzzaman and Md. Delwer Hossain / Our Nature

(2012) 10: 119-127

common habitats of $L$. calcerifer are the Bay of Bengal, commonly found in estuaries of Barishal, Patuakhali and Khulna of the south-western coastal region of Bangladesh (Rahman, 1989).

Few previous studies like Mookerjee $e t$ al. (1946), Menon (1948), Dunstan (1959), De (1971), Davis (1985), Tacon et al. (1991), Kailasam et. al., (2002) and Patnaik et al. (2011) studied food and feeding habit of Lates calcarifer around the world. This study provides an important baseline study on the seasonal variation in food composition and feeding activity of this commercially important fish at small adult stage from the south-west coastal waters of Bangladesh. The results of the study would be an effective tool for fishery biologists, managers and conservationists to initiate early management strategies and regulations for the sustainable conservation of the remaining stocks of these economically important species in the Shibsha and the Rupsha river ecosystem. Moreover, information on the on the seasonal variation in food composition and feeding activity for small adult $L$. calcerifer from the southwestern coastal region of Bangladesh are clearing lacking from literature and data bases. Therefore, the results of this study provide invaluable information for the online database, as well as providing an important baseline for future studies within the Shibsha and the Rupsha River and surrounding ecosystems such as rivers from the Mangroove ecosystem of the Sunderbans of Bangladesh.

\section{Materials and methods \\ Study site}

Specimens of $L$. calcarifer were obtained from different sites (Figure 1) from the
Rupsha and the Shibsha river, near Khulna of the south western coastal region by commercial gill net or triangular net or cast net. Both the rivers are believed to be an important spawning and feeding ground for marine fish species of south-western coastal region of Bangladesh. L. calcarifer specimens were collected monthly from the sampling sites during day time (11:0017:00 hours) from June, 2010 to July,2011 by means of traditional gill nets. Specimens were preserved in $10 \%$ buffered formalin, packed in wooden boxes and transported to the laboratory.

\section{Data analysis}

A total of 720 fish measuring $25.4-40.1 \mathrm{~cm}$ total length (TL) were examined. Total length (TL) and Alimentary canal length (ACL) was measured with a slide caliper to the nearest $0.01 \mathrm{~cm}$ and the standard length in $\mathrm{cm}$ were recorded. Fish were opened and the degree of stomach fullness was assessed according to the subjective scale described by Gravimetric method (Hynes, 1950 and Pillay, 1954). The data were then used to calculate the monthly Fullness Index (FI).

$\mathrm{FI}(\%)=$

Number of stomachs with the same degree of fullness $\times 100$ Total number of stomachs examined

The gut was then excised, weighed (g) together with its contents and preserved in $70 \%$ alcohol. Subsequently, stomach contents were suspended in water in Petri dishes and undigested prey were identified to the possible taxon using the identification keys of Smith (1977), Todd and Laverack (1991) and Needham \& Needham (1962).

The contribution of each food type to the diet and the frequency of occurrence 
Syeda Mushahida-Al-Noor, Sheikh Kamruzzaman and Md. Delwer Hossain / Our Nature (2012) 10: 119-127

were determined according to Hynes (1950). The proportion of total prey items contributed by each prey group for the entire year was determined according to the numerical method (Bowen, 1985).

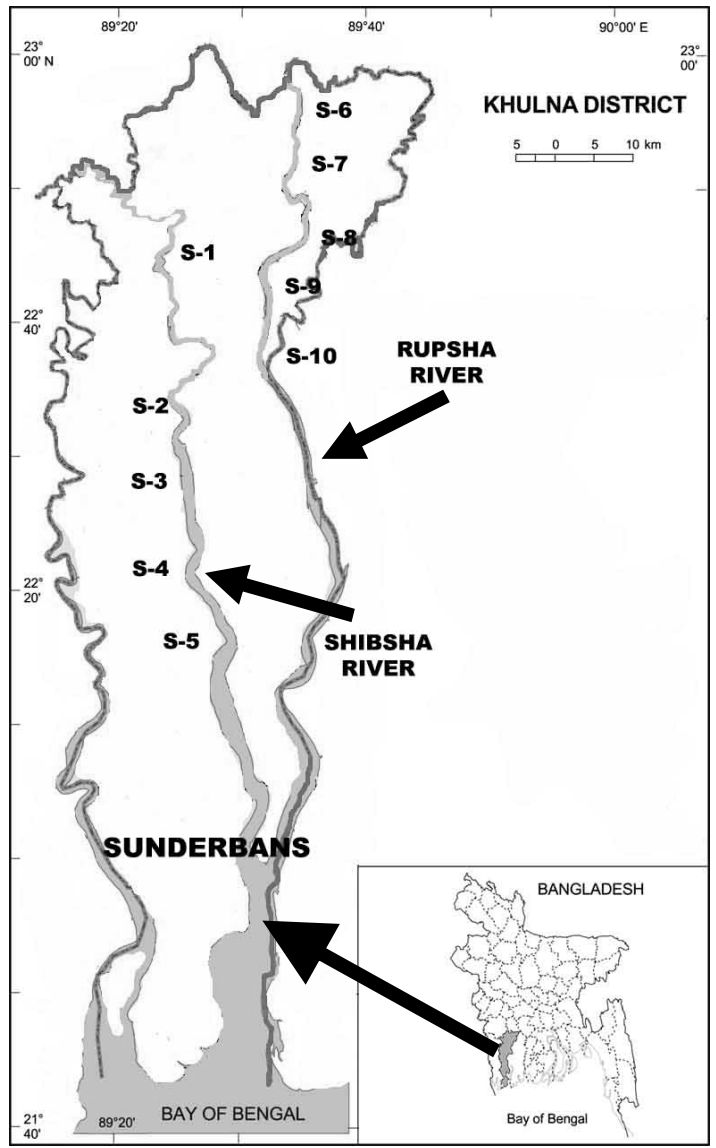

Figure 1. Map of Khulna district including sampling station of the Shibsha river (Site 1-5) and the Rupsha river (Site 6-10), southwest coast of Bangladesh

\section{Results}

The proportion of total food items contributed to each items for the entire year (Figure 2) shows that the major component of the diet was teleosts were dominant (32.40\%). Among the teleosts, Apocryptes lanceolatus, Jonieops, Otolithoides, Harpodon, Coilia dussumieri, Polynemus paradiseus, Pama pama, Therapon jarbua, Chanda nama, Lactarius lacterius, Setipinna taty, Gobiioides and Mugiloides were some identified fish groups found in the stomach of Lates calcarifer. The next major food group were macro-crustacean $(22.65 \%)$, followed by zooplankton (17.16\%), algae $(10.40 \%)$ and insects $(9.89 \%)$. The major zooplanktons items were Euglena, cladocerans (Daphnia and some others), copepodes (calanoides), shrimp larvae, megalopa larvae of crabs. Among the identified algae in the stomach of $L$. calcarifer, Coscinodiscus and Bacillariophyceae are the most expected groups. The common macro-crustacean food items of $L$. calcarifer are decapodes (Macrobrachium rosenbergii, Penaeus monodon; Metapenaeus monoceros, Caphyra and Grapsus), stomatopodes and branchiuras.

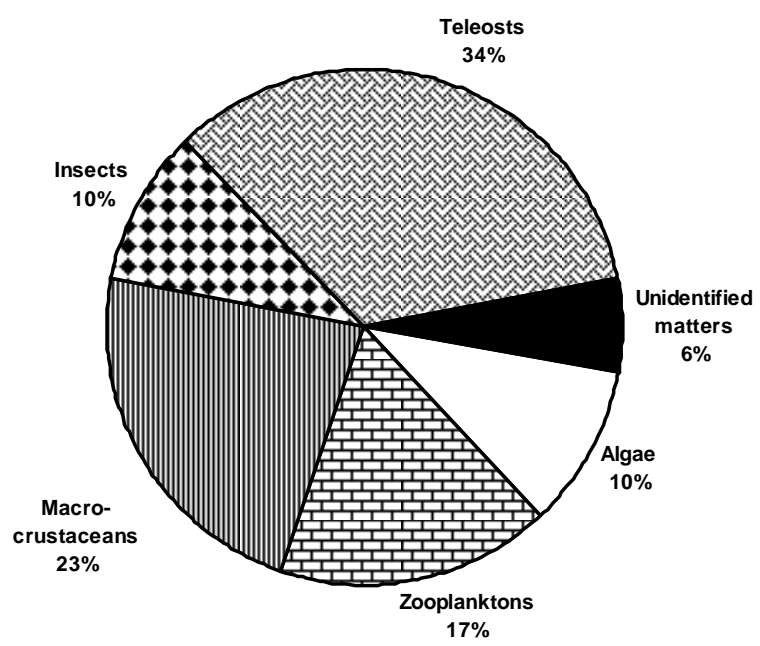

Figure 2. Proportion of food items in the stomach of small adult Lates calcarifer (July, 2010 to June, 2011 
The highest percentage $(14.5 \%)$ of algae was detected in the month of December and the lowest percentage (5.9\%) was found in April (Table 1 and Figure 3). The highest percentage $(26.9 \%)$ of zooplankton was detected in the month of July and the lowest percentage $(10.5 \%)$ was found in April. The highest percentage $(26.5 \%)$ of macro-crustacean was detected in the month of September and the lowest percentage $(16.5 \%)$ was found in July. The highest percentage $(16.5 \%)$ of insect was detected in the month of April and the lowest percentage $(6.25 \%)$ was found in December. The highest percentage $(40.5 \%)$ of teleosts was detected in the month of May and the lowest percentage $(29.5 \%)$ was found in July.

Monthly fluctuations were also witnessed in the percentage occurrence of stomachs with different degrees of fullness. It is evident that higher percentage of fullness of the stomach was recorded in premonsoon due to pre-spawning fattening process. Higher percentage of emptiness of the stomach was recorded in monsoon, due to starvation during breeding seasons. The highest number of full stomachs (richly fed and moderately fed) were found in the premonsoon period (February to May) where the lowest number of full stomachs (richly fed and moderately fed) were found in monsoon period (July and August, Figure4). The highest number of empty stomachs (empty and poorly fed) were found in the monsoon period (July and August) where the lowest number of empty stomachs (empty and poorly fed) were found in premonsoon period (February to April, Figure 4). From the study, it is also observed that the percentage of stomach fullness was higher in summer than the percentage in winter in juvenile $L$. calcarifer because both the growth and metabolism rate are positively related to the increasing temperature (Figure 4). Full stomachs were commonly occurred from November to February. 3/4 full stomachs were mostly observed in March to May. $1 / 2$ full stomachs were found in most sampled Lates calcarifer in May and July, where $1 / 3$ and $1 / 4$ full stomachs were found in June and July. $1 / 4$ full stomachs were available in $L$. calcarifer averagely almost in April to July, where empty stomachs were observed averagely throughout the year except October and December in L. calcarifer.

\section{Discussion}

In present study, the food composition of juvenile $L$. calcerifer, breeding season (monsoon season) and seasonal fluctuation (summer and winter) has an effect on stomach contents such as variation of food items. For this reason, the stomach consists of significant percentage teleosts, macrocrustacean, zooplanktons, insects and algae. Analysis of monthly variations in stomach fullness indicated that feeding intensity fluctuated throughout the year. This maximum number of empty stomachs was observed during winter and a minimum number observed during summer. On the other hand, most of the richly and moderately fed stomach is observed in Lates calcerifer during pre-monsoon periods and most of the poorly fed stomach is observed in Lates calcerifer during monsoon periods. These finding can be compared to several previous studies on the food and feeding habits of Bass groups.

Ferry et al. (1997) listed fishes, crustaceans, echinoderms, and mollusks as the main food items for Spotted sand bass 
Syeda Mushahida-Al-Noor, Sheikh Kamruzzaman and Md. Delwer Hossain / Our Nature (2012) 10: 119-127

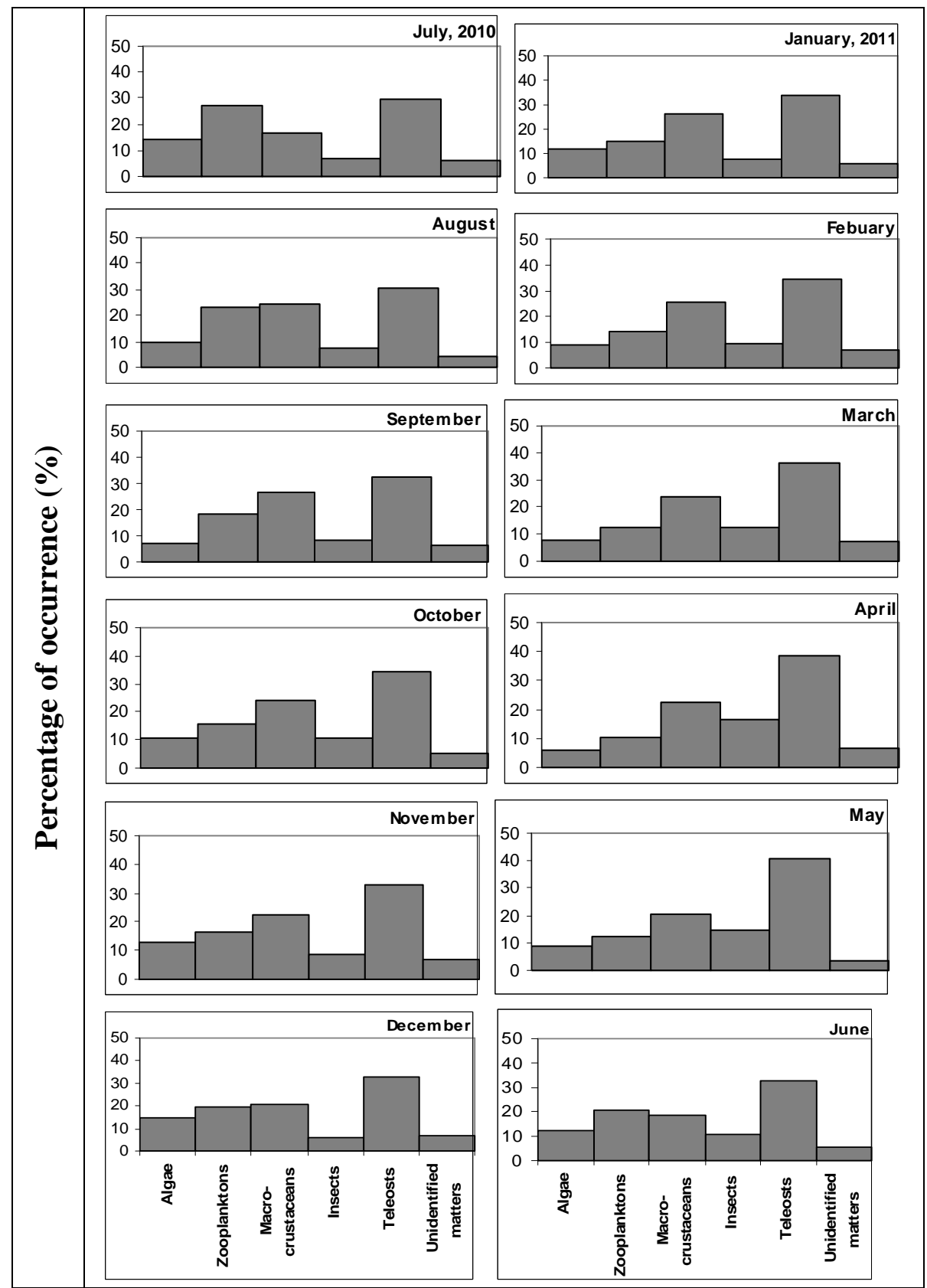

Figure 3. Mean percentage frequency of occurrence of different food groups in the stomach of small adult $L$. calcarifer during the study periods 
Syeda Mushahida-Al-Noor, Sheikh Kamruzzaman and Md. Delwer Hossain / Our Nature (2012) 10: 119-127

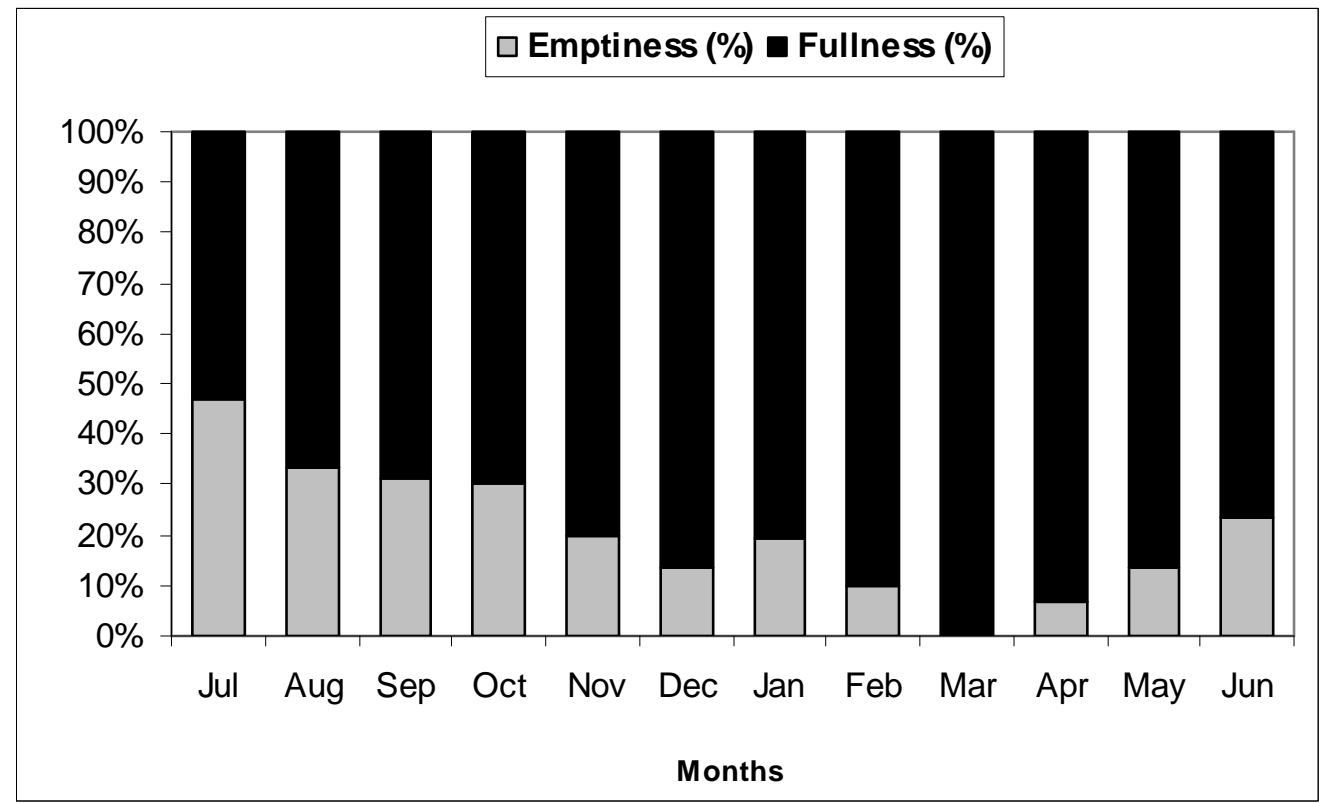

Figure 4. Monthly variation of stomach fullness and emptiness of small adult L. calcarifer from July, 2010 to June, 2011

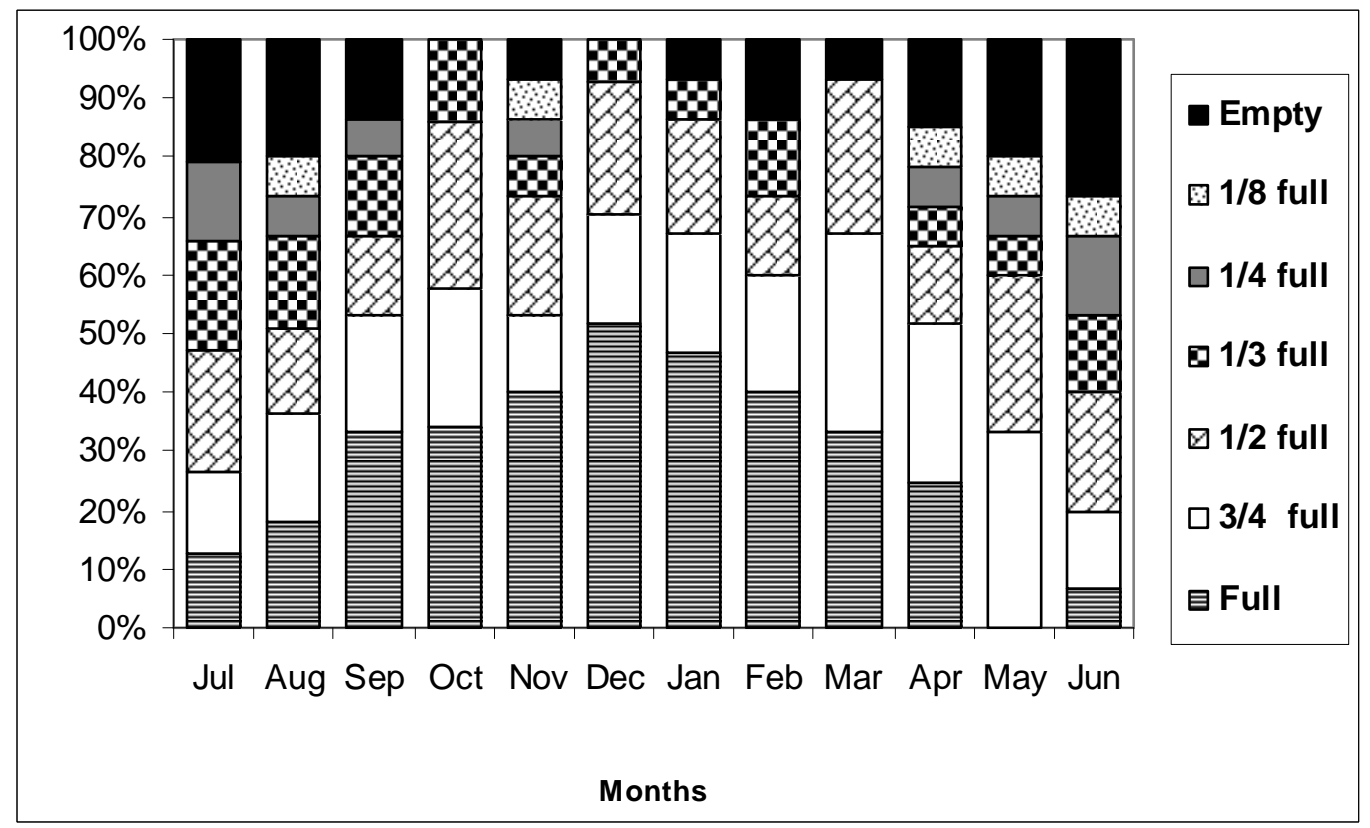

Figure 5. Monthly variation of stomach fullness of small adult Lates calcarifer during the study periods 
Syeda Mushahida-Al-Noor, Sheikh Kamruzzaman and Md. Delwer Hossain / Our Nature

(2012) 10: 119-127

Table 1. Monthly variation in the percentage occurrence of various groups of food items in the stomachs of small adult $L$. calcarifer during the study period ( $\mathrm{n}=60$ in each month, total of 720 specimens).

\begin{tabular}{|l|l|c|c|c|c|c|c|}
\hline \multicolumn{2}{|c|}{ Year and months } & Algae & Zooplankton & $\begin{array}{c}\text { Macro- } \\
\text { crustacean }\end{array}$ & Insects & Teleosts & Unidentified \\
\hline \multirow{5}{*}{2010} & July & 14.5 & 26.9 & 16.5 & 6.5 & 29.5 & 6.1 \\
\cline { 2 - 8 } & August & 9.9 & 23.4 & 24.5 & 7.5 & 30.7 & 4 \\
\cline { 2 - 8 } & September & 7.25 & 18.5 & 26.5 & 8.5 & 32.5 & 6.75 \\
\cline { 2 - 8 } & October & 10.5 & 15.8 & 24.2 & 10.4 & 34.2 & 4.9 \\
\cline { 2 - 8 } & November & 12.9 & 16.5 & 22.5 & 8.5 & 32.8 & 6.8 \\
\cline { 2 - 8 } & December & 14.5 & 19.3 & 20.5 & 6.25 & 32.9 & 6.5 \\
\hline \multirow{5}{*}{2011} & January & 11.6 & 15.3 & 26.2 & 7.5 & 33.5 & 5.9 \\
\cline { 2 - 8 } & February & 9.2 & 14.1 & 25.8 & 9.5 & 34.5 & 6.9 \\
\cline { 2 - 8 } & March & 7.5 & 12.5 & 23.6 & 12.5 & 36.5 & 7.4 \\
\cline { 2 - 7 } & April & 5.9 & 10.5 & 22.5 & 16.5 & 38.2 & 6.4 \\
\cline { 2 - 8 } & May & 8.5 & 12.5 & 20.5 & 14.5 & 40.5 & 3.5 \\
\cline { 2 - 8 } & June & 12.5 & 20.7 & 18.5 & 10.5 & 32.4 & 5.4 \\
\hline
\end{tabular}

from Los Angeles Bay in the Gulf of California. Mendoza-Carranaza et al. (2000) studied food and feeding habit of Spotted sand bass (Paralabrax maculatofsciatur) for the Punta Banda Estuary, Baja California and found that this fish takes prominently crustacean and teleostei and elagrass, mollusks and zooplankton as their food. In the stomach of $P$. maculatofsciatur, Decapods represented the highest percentage of weight $(64.0 \%)$ and frequency of occurrence $(84.2 \%)$. Gammarids constituted the highest numeric percentage $(70.7 \%)$. The feeding habits of Barred sand bass (Purulubrax nebulifer) are described by Roberts et al. (1984) where the study showed that Bass of intermediate size (240$320 \mathrm{~mm} \mathrm{SL}$ ) contained the species found in both large and small fish. Seasonal changes in feeding have been observed in the kelp bass (Purulubrux cluthrutus; Quast 1968) and barred sand bass ( $P$. nebulifir; Love and Ebeling 1978). Fujita et al.(1988) studied the food and feeding habit of juvenile (12.3$20.0 \mathrm{~cm}$ total length) Temperate bass Lateolabrax latus and Lateolabrax japonicus in Shimanto Estuary in Japan. He showed that copepoda (65.0\%) and cladocera (33.4\%) are the dominant groups of foods in Lateolabrax japonicus. On the other side, copepoda(70.3\%) and fish larvae $(20.0 \%)$ are the dominant groups of foods in Lateolabrax latus. Katunzi et al.(2006) observed spatial and seasonal patterns in the feeding habits of juvenile Lates niloticus in the Mwanza gulf of lake Victoria. In his study it is observed that, at a size of $3-4 \mathrm{~cm}$ Nile perch shifted from cyclopoids to calanoids. Kishe-Machumu e. al (2012) showed that shrimp (Caridina nilotica) and haplochromine cichlids were the most common prey types in Lates niloticus. Other studies on Largemouth bass fry (Micropterus salmoides) proved that feed mainly on micro-crustaceans and small insects, juveniles consume mostly insects and small fish, and adults feed primarily on fish and crayfish (Carlander, 1977 and Stuber et al., 1982).

\section{Acknowledgements}

The authors are grateful to all members of teaching and non-teaching staff of the Department of Fisheries, University of 
Syeda Mushahida-Al-Noor, Sheikh Kamruzzaman and Md. Delwer Hossain / Our Nature (2012) 10: 119-127

Rajshahi, for technical assistance and valuable suggestion during the study.

\section{References}

Allen, G.R., S.H. Midgley and M. Allen,, 2002. Field guide to the freshwater fishes of Australia. Western Australian Museum, Perth, Western Australia. 394 p.

Bianchi, G., 1985. FAO species identification sheets for fishery purposes. In: Field guide to the commercial marine and brackish-water species of Pakistan. Prepared with the support of PAK/77/033 and FAO (FIRM) Regular Programme. Rome: FAO. 200 p.

Bowen, S. H. ,1985. Quantitative description of the diet. L.A. Nielson, D.L. Jhonson and S. Lampton (Eds.) Blacksburg fisheries Techniques, pp. 325336.

Carlander, K.D., 1977. Handbook of Freshwater Fishery Biology. Vol. 2. Iowa State University Press, Ames, IA, USA.

Cheung,W.W.L., T.J. Pitcher and D. Pauly, 2005. A fuzzy logic expert system to estimate intrinsic extinction vulnerabilities of marine fishes to fishing. Biol. Conserv. 124:97-111.

Das, N.G., 2000. Development of Breeding Technology of Bhetki Lates calcarifer, Bangladesh Agricultural Research Council, 18 pp.

De, G. K.,1971. On the biology of postlarvae and juvenile stages of Lates calcarifer (Bloch). J. Indian Fish. Ass. 1 (2): 51-64.

Dunstan, D. J., 1959. The Barramundi Lates calcarifer (Bloch) in Queensland waters C.S.I.R.O. Australia Div. Fish \& Oceangr. Tech. paper No. 5: 22p.

Ferry, L. A., S. L. Clark, and G. M. Calliet,1997. Food habits of spotted sand bass from the LosAngeles, Baja California. South. Calif. Acad. Sci. 16(1):1-17.

Fujita S.,Kinoshita I.,Takahashi I. and Azuma K.,1988. Seasonal cuurance and food habits of larvae and Juviniles of Two Temparate Basses in the Shimanto Estuary, Japan.Japanese Journal of ichthyology.35(3):365-370.

Hla Win, U., 1987. Checklist of fishes of Burma. Ministry of Livestock Breeding and Fisheries, Department of Fisheries, Burma.

Hynes, H.B.N.,1990: The food of freshwater stickleback with a review of the methods used in studies of fishes. J. Anim. Ecol. 19: 41-57.
Kailasam M., Thirunavukkarasu A.R.,Abraham M., Chandra P. K. and Subburaj R., 2002. Influence of size variation and feeding on cannibalism of Asian sea bass Lates calcarifer (Bloch) during hatchery rearing .Indian J. Fish., 49(2): 107-111.

Kapoor,D., R. Dayal and A.G. Ponniah, 2002. Fish biodiversity of India. National Bureau of Fish Genetic Resources Lucknow, India.775 p.

Katunzi E.F.B.,Van Densen W.L.T., Wanink J.H. \& Witte F., 2006. Spatial and seasonal patterns in the feeding habits of juvenile Lates niloticus (L.), in the Mwanza Gulf of Lake Victoria. Hydrobiologia $.568: 121-133$

Kishe-Machumu M.A., Witte F.,Wanink J. H., Katunzi E.F.B., 2012. The diet of Nile perch, Lates niloticus (L.) after resurgence of haplochromine cichlids in the Mwanza Gulf of Lake Victoria. Hydrobiologia. 682:111-119

Kungvankij, P.; Pudadera, B.J.; Tiro, J.R.L.B. and Potestas, I.O., 1986. Biology and culture of sea bass (Lates calcarifer), NACA training manual series No. 3, Bangkok, Thailand, 70 pp.

Love, M. S., and A. W. Ebeling., 1978. Food and habitat of three switch feeding fishes in the kelp forest off Santa Barbara, California. Fish. Bull. 76(1):257-271.

Luna, S., 2008. "Lates calcarifer, Barramundi: fisheries, aquaculture, gamefish, aquarium:"FishBase. Accessed April 02, 2008. http://fishbase.sinica. edu.tw/summary/speciessummary.php?genusname $=$ Lates\&speciesname $=$ calcarifer

Mendoza-Carranaza M. and Rosales-Casian J. A., 2000. The feeding habits of Spotted sand bass (Paralabrax maculatofaciatus) in Punta banda estuary, Ensenada, Baja California, Mexico. CalCOFl Rep., 41:194-199.

Mennon, P. M. G., 1948. On the food of the 'Bekti' Lates calcarifer (Bloch) in the cold season, Curr. Sci., 17: 156-157.

Mookerji, H. K., Ganguly D.N. and Majumdar T.C., 1946. On the food of estuarine fishes of Bengal. Sci. and Cult., 11: 564-65.

Needham, J.G. \& Needham, P.R., 1962. Guide to the Study of Freshwater Biology. 5th edition. Holden day Inc. San Francisco. 108 pp.

Pethiyagoda, R., 1991. Freshwater fishes of Sri Lanka. The Wildlife Heritage Trust of Sri Lanka, Colombo. 362 p.

Pilley, T.V.R., 1952. A critique of the methods of study of food of fishes. J. Zool. Soc. India. 4(2): 185-200. 
Syeda Mushahida-Al-Noor, Sheikh Kamruzzaman and Md. Delwer Hossain / Our Nature (2012) 10: 119-127

Quast, J. C., 1968. Observations on the food and biology of the kelp-bass(Purulubrux cluthrutus).Calif. Dep. Fish Game, Fish. Bull. 139:81-108.

Rahman, A.K.A., 1989. Freshwater Fishes of Bangladesh, 1st edition, Zoological Society of Bangladesh, Department of Zoology, University of Dhaka, Dhaka-1000, pp. 337-338.

Roberts D.A., DeMartini E. E., and Plummer K. M., 1984. The feeding habits of Juvinile-Small adult Barred sand bass (Paralabrax nebulifer) in nearshore waters of Norhern San Diego county. CalCOFI Rep., XXV:110-112.

Smith,B.L. ,1977. A guide to marine coastal plankton and marine invertebrate larva. Hunt Publishing Company. California.161 pp.

Stuber, R.J., G. Gebhart, and O.E. Maughan., 1982. Habitat Suitability Index Models: Largemouth
Bass. US Department of Interior, Washington, DC, USA.

Tacon, A.G.J.; Rausin, N.; Kadari, M. and Cornelis, P. 1991. The food and feeding of tropical marine fishes in floating net cages: Asian seabass, Lates calcarifer (Bloch), and brown-spotted grouper, Epinephelus tauvina (Forskal), Aquaculture and Fisheries Management, 22: 165-182.

Todd C.D. and Levarak M.S., 1991.Coastal marine zooplankton: A practical manual for students. Cambridge University press.Cambridge. $106 \mathrm{pp}$.

Whitehead, P.J.P., 1984. Centropomidae. In: FAO species identification sheets for fishery purposes. Western Indian Ocean (Fishing Area 51). vol. 1. FAO, Rome.

Yadav, B.N., 1999. Fish and fisheries, Daya Publishing House, New Delhi, India. 366 pp. 